Sachin Pawar, Abhijeet Birari, and Jitendrasinh Jamadar

\title{
COVID-19, LOCKDOWN AND ITS EFFECT ON CONSUMPTION BEHAVIOR OF HOUSEHOLD: EVIDENCE FROM MAHARASHTRA STATE, INDIA
}

\begin{abstract}
The purpose of this paper is to assess the effect of COVID-19, nationwide lockdown, and measures taken by the central bank to adjust the consumer behavior of households in Maharashtra, India. This study used a structured questionnaire to achieve the objectives with a sample size of 221 and statistical tools like Logistics regression, Kruskal Wallis Test, Wilcoxon Signed Rank Test, and Chi-Square Test. The results indicate that COVID-19 decreased the consumption of the household and that there was a significantly positive relationship between the level of consumption during lockdown and age, gender, number of dependents, income, education level, and region. People tend to lower their consumption for non-essential categories and increase for essential ones. The current study is considered the first of its kind conducted in Maharashtra, India. To the best of our knowledge, there were no such studies regarding measuring the impact of COVID-19 on household consumption.

Keywords: COVID-19, Consumption, Household, Spending
\end{abstract}

\section{Sachin Pawar}

People's College

Abhijeet Birari

MGM Institute of Management and Research

Jitendrasinh Jamadar

MGM Institute of Management and Research

Correspondence: Abhijeet Birari

MGM Institute of Management and Research, Aurangabad

E-mail:biraria@gmail.com 


\section{INTRODUCTION}

The 2019-20 coronavirus pandemic is an ongoing pandemic of coronavirus disease 2019 (COVID-19) caused by severe acute respiratory syndrome coronavirus. The first case was identified in Wuhan, China, in December 2019 and declared to be a public health emergency of international concern on 30 January 2020, and recognized as a pandemic by the World Health Organization on 11 March 2020. As of 14 April 2020, more than 1.92 million cases of COVID-19 have been reported in 210 countries and territories, resulting in more than 119,000 deaths. More than 453,000 people have recovered, although there may be a possibility of relapse or re-infection. The case fatality rate was estimated to be 4 percent in China, but varies significantly between countries.

The virus is mainly spread between people through close contact, often via small droplets produced during coughing, sneezing, or talking. While these droplets are produced when breathing out, they usually fall to the ground or onto surfaces rather than being infectious over large distances. People may also become infected by touching a contaminated surface and then their face. The virus can survive on surfaces for up to 72 hours. It is most contagious during the first three days after onset of symptoms, although spread may be possible before symptoms appear and in later stages of the disease. Common symptoms include fever, cough, and shortness of breath. Complications may include pneumonia and acute respiratory distress syndrome. The time from exposure to onset of symptoms is typically around five days but may range from two to fourteen days. There is no known vaccine or specific antiviral treatment. Primary treatments are symptomatic and supportive therapies. Recommended preventive measures include:

- Hand washing,

- Covering one's mouth when coughing,

- Maintaining distance from other people and

- Monitoring and self-isolation for people who suspect they are infected.

Authorities worldwide have responded by implementing travel restrictions, quarantines, curfews, and stay-at-home orders, workplace hazard controls, and facility closures.

The pandemic has led to severe global socioeconomic disruptions, the postponement or cancellation of sporting, religious, political, and cultural events, and shortages of supplies exacerbated by panic buying. Schools, universities, and colleges have closed either on a nationwide or local basis in 210 countries, affecting approximately 99.9 
percent of the world's student population. Misinformation about the virus has spread online, and there have been incidents of xenophobia and discrimination against Chinese people and against those perceived as being Chinese or as being from areas with high infection rates. Due to reduced travel and closures of heavy industry, there has been a decrease in air pollution and carbon emissions. The objectives of the study are as below:

1. To study the impact of the pandemic on household consumption.

2. To study the impact of COVID-19 pandemic on earning and employment of individuals.

3. To study the prospects of individuals in the post COVID-19.

\section{ORIGIN}

Health authorities in Wuhan, China (the capital of Hubei province), reported a cluster of pneumonia cases of unknown cause on 31 December 2019, and an investigation was launched in early January 2020. The cases mostly had links to the Huanan Seafood Wholesale Market, and the virus has been thought to have a zoonotic origin. The virus, which caused the outbreak, has been known as SARS-CoV-2, a newly discovered virus closely related to bat coronaviruses, pangolin coronaviruses, and SARS-CoV.

The earliest known person who had symptoms was discovered later to have fallen ill on 1 December 2019, and that person did not have visible connections with the later wet market cluster. Of the early cluster of cases reported in December 2019, two-thirds were found to have a link with the market. On 13 March 2020, an unverified report from the South China Morning Post suggested a case traced back to 17 November 2019, in a 55-year-old from Hubei province, may have been the first.

\section{Measures taken by India to prevent the spread of coronavirus}

Taking rapid actions to limit travel by suspending visas and quarantining all incoming travelers has helped. All international passengers entering India undergo universal health screening. According to health officials, more than 1 million passengers have been screened at airports, limiting the entry coronavirus. The response also mirrors India's reaction to previous disease outbreaks, including Ebola in 2014 and Nipah in 2018, when people were quickly put into quarantine or under surveillance. Indian citizens have been advised to avoid all non-essential travel abroad, and citizens have been evacuated from 
Iran, Italy, China, and Japan. Apart from ensuring the safe return of hundreds of Indians from China, Iran, and other countries, the Indian government has taken decisive measures to contain community spread," said Sriram Gutta, Head of Community Development, India and South Asia at the World Economic Forum. "While these measures will have a short-term economic impact, they will ensure the safety and welfare of Indians." (Emma, 2020). Prime Minister Narendra Modi’s government was quick to recommend residents avoid or postpone mass gatherings until the virus is contained. The Ministry of External Affairs postponed the Indian cricket league and state authorities are shutting schools, gyms, and swimming pools in the worst-hit regions. A "novel coronavirus" landing page on the Ministry of Health's website gives the numbers of phone helplines, as well as detailed advice and guidelines. Actions like these have been lauded by the World Health Organization (WHO), which is leading the global charge against the virus. Such responses are "good and impressive," according to the WHO. "India is doing quite well," said the WHO representative, Henk Bekedam. Even so, the nation still faces many of the same challenges as other countries, including limiting unauthorized gatherings and debunking fake health messages circulating on social media. The global economic impact will be hard to avoid, with the United Nations trade and development agency predicting the slowdown in the global economy caused by the coronavirus outbreak is likely to cost at least $\$ 1$ trillion.

The Director-General of the Indian Council of Medical Research Balram Bhargava said on Tuesday that community transmission of COVID-19 has not yet occurred in India, meaning people who contracted the virus did so from a known source. Even so, officials are preparing for it to happen, with private laboratories authorized to test for the virus, freeing up more capacity for diagnosis and detection. Restaurants are also shutting, with the National Restaurants Association advising members to close at least until May 3, 2020. Under the new measures, all non-essential businesses will be closed but hospitals and other medical facilities will continue to function as normal. Schools and universities will remain shut and almost all public gatherings will be banned. Anyone flouting the new rules faces up to two years in prison and heavy fines.

In his address, Prime Minister Modi also:

- Stressed that the lockdown was "very necessary to break the chain of coronavirus"

- $\quad$ Emphasized the seriousness of the situation and said that even developed countries had faced problems in combating it 
- $\quad$ Said that "social distancing was the only way to stop" the virus spreading

- $\quad$ Announced that nearly $\$ 2 \mathrm{bn}(£ 1$.8bn) would be made available to boost the country's health infrastructure

- $\quad$ Called on people not to "spread rumors" and to follow instructions

His announcement came after several Indian states introduced measures of their own, such as travel restrictions and the closure of non-essential services. India has already issued a ban on international arrivals and grounded domestic flights. The country's rail network has also suspended most passenger services.

\section{LITERATURE REVIEW}

Amory, Markhvida, Hallegatte, and Walsh (2020) concluded that without any social protection, COVID-19 would lead to a massive economic shock to the system. In simulations of a 3-month lockdown, the poverty rate has increased from $17.1 \%$ to $25.9 \%$ during the crisis. Household savings and consumption drop significantly, and the average recovery time for individuals is almost one year. The long recovery time after the crisis will be further exacerbated by a general decrease in demand, people's change in consumer behavior, and a general slowdown of economic activities

Scott, Farrokhnia, Steffen, Michaela, and Constantine (2020) explored how household consumption was impacted by epidemics, utilizing transaction-level household financial data to investigate the impact of the COVID-19 virus. As the number of cases grew, households began to radically alter their typical spending across a number of categories of goods. Initially spending increased sharply, particularly in retail, credit card spending, and food items. This was followed by a sharp decrease in overall spending. Households responded most strongly in states with shelter-in-place orders in place by March 29, 2020. We explore heterogeneity across partisan affiliations, demographics, and incomes. Greater levels of social distancing are associated with drops in spending, particularly in restaurants and retail.

Silvius, Radu, Sapira, Bratoveanuand, and Mirel (2020) studied that the health of the consumers (purchase of medicines or visit to the physician), procuring food, or financial activities at the banking units are the main motivations for leaving the residences. By comparison, the demands for visiting sports activities or family members were plunged. A segment of consumers, an advocate of traditional commerce, has been forced to appeal 
to modern trade methods based on online shopping, and the specialists' estimations provide the maintenance of the trading behavior

Haiqiang, Qian, and Wen (2020) found that daily offline consumption-via bank card and mobile QR code transactions-fell by $32 \%$, or 18.57 million RMB per city, during the twelve-week period. Spending on goods and services were both significantly affected, with a decline of $33 \%$ and $34 \%$, respectively; within finer categories, dining \& entertainment and travel saw the greatest dip of $64 \%$ and $59 \%$. The consumption decrease is prevalent across cities with the largest drop occurring in the epicenter Wuhan (by $70 \%$ ). Consumption responded negatively to the day-to-day changes in epidemic severity while distancing measures remained stable. Consumption had rebounded back to the baseline level by the end of March 2020 but dropped to -20\% in early April 2020 due to the elevated risk of a second wave of infections. We infer that China's offline consumption decreased by over 1.22 trillion RMB in the three-month post-outbreak period or $1.2 \%$ of China's 2019 GDP. Our estimates suggest a significant economic benefit of containing the virus through a lessened consumption decrease and a faster consumption recovery.

A large literature finds the economic consequences of diseases are significant (Fan, Dean, and Lawrence, 2016). Specifically, large-scale viral diseases have a significant longterm impact on GDP and per-capita income (Bloom and Ajay, 1997; Sachs and Pia, 2002), human capital accumulation (Almond, 2006; Bleakley, 2007; Young, 2005), house prices, and urban landscape (Ambrus, Erica, and Robert, 2020). Given the glaring concern over the COVID-19 pandemic, economists have started to identify and estimate the potential economic impact (Atkeson, 2020; Barro, José, and Joanna, 2020; Gormsen and Ralph, 2020). We use high-frequency transaction-based consumption data to quantify the aggregate consumption impact of COVID-19 and relate it to the epidemic severity both in the cross-section and over time. The draft includes estimates for 30 countries, under different scenarios.

The report shows the economic effects of the outbreak are currently being underestimated, due to over-reliance on historical comparisons with SARS, or the 2008/2009 financial crisis.

At the date of the report, the duration of the lockdown, as well as how the recovery will take place is still unknown. That is why several scenarios are used. In a mild scenario, GDP growth would take a hit, ranging from 3-6\% depending on the country. As a result, in the sample of 30 countries covered, we would see a median decline in GDP in 
2020 of $-2.8 \%$. In other scenarios, GDP can fall more than $10 \%$, and in some countries, more than $15 \%$.

Fernandes (2020) studied that service-oriented economies will be particularly negatively affected and have more jobs at risk. Countries like Greece, Portugal, and Spain that are more reliant on tourism (more than 15\% of GDP) will be more affected by this crisis. This current crisis is generating spillover effects throughout supply chains. Therefore, countries highly dependent on foreign trade are more negatively affected. The results suggest that on average, each additional month of crisis costs $2.5-3 \%$ of global GDP.

Saraswathy (2021) stated that the COVID-19 outbreak in India and the subsequent nationwide lockdown from March 252020 altered the landscape of the country's employment sector. With close to 10.9 million jobs being lost across sectors, 2020 was termed the worst-ever year for the job market in India.

Davis (2021) concluded that consumption, time allocations, and health outcomes have all been significantly affected by the pandemic and ensuing policy responses, but the responses have been rather heterogeneous across regions, individuals, and outcomes.

Arpit, Anup, and Bartek (2021) estimated large and heterogeneous drops in income, with ambiguous effects on inequality. While incomes of salaried workers fell 35\%; incomes of daily laborers fell $75 \%$. The consumption of food and fuel fell less than consumption of durables such as clothing and appliances.

Paula and Liviu (2014) found that the association between consumption and income is stronger in low- and high-income countries, compared with middle-income countries, a logical conclusion since the high-income countries allocate more capital to investments and are intensely specialized in research and development activities.

\section{HYPOTHESES}

Based on the existing literature and its subsequent analysis, it is found that there is certain empirical evidence based on which following hypothesis is drawn. As per Paula and Liviu (2014), it is found that there is an association between consumption and income in mostly low- and high-income countries. On the basis of this argument, we hypothesize that there is a positive significant relationship between the level of 
consumption and age, gender, employment status, number of dependents, incomes, and education levels during COVID-19 (H1).

Scott et. al. (2020) found that as the number of COVID cases grew, households began to radically alter their typical spending across a number of categories of goods. Hence, we theorize that the pandemic will adversely affect household consumption (H2).

Arpit et. al. (2021) estimated that there was a drop-in income of salaried and daily laborers and the consumption of food and fuel fell less than consumption of consumer durables. Based on this, we argue that the household consumption post COVID-19 pandemic will be significantly lower than pre COVID era (H3).

Saraswati (2020) and Arpit et. al. (2021) argued that the COVID-19 pandemic has impacted the earning as well as employment in the country. That forms the basis for H4 and $\mathrm{H} 5$.

\section{Hypotheses}

Hypothesis 1: There is positive significant relationship between level of consumption and age, gender, employment status, number of dependents, incomes and education levels during COVID-19

Hypothesis 2: COVID-19 pandemic will adversely affect consumption pattern of individuals

Hypothesis 3: The household consumption post COVID-19 will be significantly lower than pre COVID-19 era.

Hypothesis 4: COVID-19 pandemic will adversely impact individual earning

Hypothesis 5: COVID-19 pandemic will adversely impact the individual employment

\section{RESEARCH METHODOLOGY}

\section{Questionnaire design}

A structured questionnaire was used by researchers to analyze the impact of the COVID-19 pandemic and lockdown on household consumption behavior during and after the lockdown. In the current study, only objective measures and closed-ended questions were used to assess this impact.

The questionnaire consists of 16 questions of which 7 were related to demographic and socioeconomic information like age, gender, employment status, number of 
dependents, incomes, education levels, and regions. Among the 16 questions, 3 questions, of which each contain 12 categories of household consumption, were asked to find the consumption before, during, and after the lockdown due to COVID-19 pandemic. The consumption categories were based on several studies that have attempted to examine household consumption/spending in various countries. The other 3 questions were included to understand the perception of respondents towards potential loss of job/business or earning due to pandemic. One of the important decisions taken by Reserve Bank of India (RBI) was regarding allowing moratorium on term loans up to 3 months hence 3 questions were also asked to know the respondent's decision and priorities to the debt repayment.

The questionnaire is divided into five parts. The first part covers socioeconomic and demographic factors. The second part identifies respondents' consumption behavior based on 12 consumption categories (food, personal spending, medical and healthcare, transport, entertainment, education, utilities, housing, insurance, saving, investing, debt payments) during lockdown using the 5-point Likert scale ranging from 1 (very low consumption) to 5 (very high consumption). The third part is devoted to comparing pre and post lockdown consumption levels of respondents. Pre-lockdown consumption included questions related to consumption on 12 categories on the 3 point Likert scale ranging from 1 (Low) to 3 (High). For the comparison, questions were included to know whether the consumption of each category is likely to increase, decrease, or remain constant in the future (post lockdown) considering 12 months period. The fourth part included questions to know the perception of respondents regarding the possible loss of job or income due to the pandemic and decisions that they will make in such a case. The last part was about the decision regarding opting for the moratorium on term loans. The questionnaire was piloted on 30 respondents. Accordingly, the researchers made changes and reformulated some questions.

\section{Sampling and data collection}

The study was focused on working professionals and businessmen in Maharashtra State, India. Given the wide socio-economic diversity, the sample was drawn from five regions of the state (Marathwada, Vidarbh, Khandesh, Konkan, and West Maharashtra).

Data was collected through a survey in April 2020 by using Google form through convenient sampling. The survey was sent to 758 people (through E-mail) and though the target sample size was 300 , after preliminary analysis of the data, the usable sample, with 
information on all dimensions and variables, was reduced to 221 whereas remaining were excluded because of incomplete data or response bias of extreme values. Table 1 presents the detailed distribution of the sample across various attributes.

\section{Regression model}

To identify the effect on the level of consumption of each of the following independent variables: age, gender, employment status, number of dependents, incomes, education levels, and regions, the ordinal logistics regression model was used. The coefficients represent the effect of each subgroup compared with a reference group, which is arbitrarily selected. For example, gender is coded as 1 for female, and as 0 for male. For gender, the reference group is female participants. For age, the reference category is respondents (coded as 0 ) above 55 years of age. For incomes, the reference group is respondents with more than Rs. 1,00,000 monthly salary. For education variables, the reference category is respondents with post-graduate degrees. For the number of dependents, the category with more than 5 is the reference group and for the region, Paschim Maharashtra is taken as the reference category.

The logistic regression model is as follows:

$$
\begin{aligned}
\operatorname{In}\left(\frac{p}{1-p}\right) L C= & \beta_{0}+\beta_{1}\left(G E N_{1}\right)+\beta_{2}\left(A G E_{1}\right)+\beta_{3}\left(A G E_{2}\right)+\beta_{4}\left(A G E_{3}\right)+\beta_{5}\left(A G E_{4}\right) \\
& +\beta_{6}\left(I N C_{1}\right)+\beta_{7}\left(I N C_{2}\right)+\beta_{8}\left(I N C_{3}\right)+\beta_{9}\left(I N C_{4}\right)+\beta_{10}\left(I N C_{5}\right) \\
& +\beta_{11}\left(E D U_{1}\right)+\beta_{12}\left(E D U_{2}\right)+\beta_{13}\left(E D U_{3}\right)+\beta_{14}\left(E D U_{4}\right) \\
& +\beta_{15}\left(D E P_{1}\right)+\beta_{16}\left(D E P_{2}\right)+\beta_{17}\left(D E P_{3}\right)+\beta_{18}\left(D E P_{4}\right)+\beta_{19}\left(D E P_{5}\right) \\
& +\beta_{20}\left(D E P_{6}\right)+\beta_{21}\left(R E G_{1}\right)+\beta_{22}\left(R E G_{2}\right)+\beta_{23}\left(R E G_{3}\right) \\
& +\beta_{24}\left(R E G_{4}\right)+e_{i}
\end{aligned}
$$

Where:

$$
\begin{array}{ll}
\mathrm{LC} & =\text { Level of consumption during lockdown } \\
\mathrm{p} & =\text { Probability of respondent with relatively more level of spending } \\
\beta_{0} & =\text { Intercept } \\
\beta_{1} \text { to } \beta_{24} & =\text { Coefficients } \\
\mathrm{GEN}_{1} & =1 \text { if respondent is male, } 0 \text { otherwise } \\
\mathrm{AGE}_{1} & =1 \text { if respondent is in age group of } 18-25,0 \text { otherwise } \\
\mathrm{AGE}_{2} & =1 \text { if respondent is in age group of } 26-35,0 \text { otherwise }
\end{array}
$$




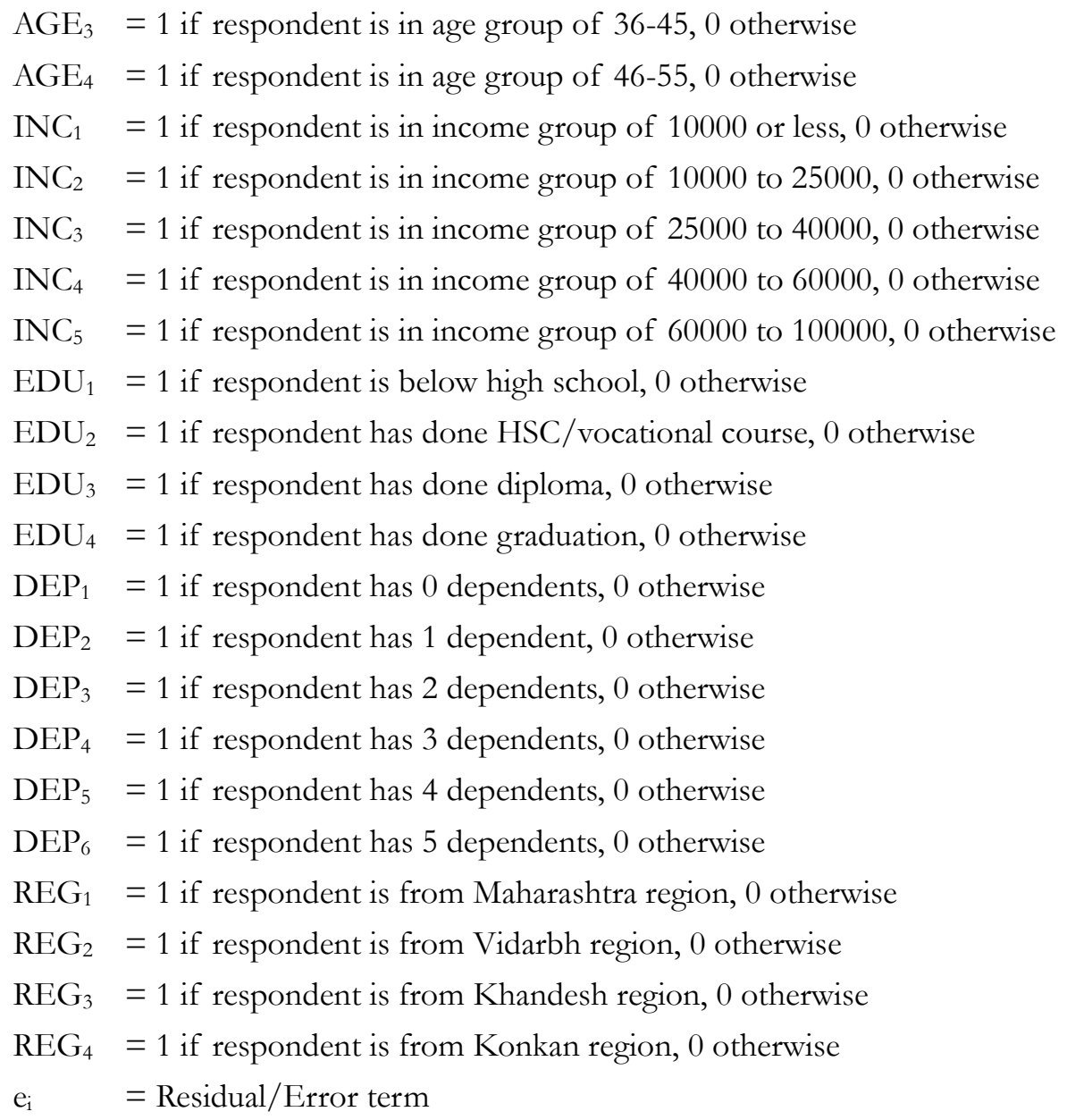

\section{RESULTS AND DISCUSSION}

\section{Profile of respondents}

The questionnaire asked respondents to provide demographic and socio-economic data that included age, gender, employment status, number of dependents, incomes, education levels, and regions. Table 1 provides descriptive statistics for the respondents' characteristics. 
Table 1. Respondents' Profile

\begin{tabular}{|c|c|c|}
\hline Variable & Number & Percentage \\
\hline Sample size & 221 & $100 \%$ \\
\hline \multicolumn{3}{|l|}{ Gender } \\
\hline Female & 36 & $16.29 \%$ \\
\hline Male & 185 & $83.71 \%$ \\
\hline \multicolumn{3}{|l|}{ Age (in Yrs.) } \\
\hline $18-25$ & 44 & $19.91 \%$ \\
\hline $26-35$ & 70 & $31.67 \%$ \\
\hline $36-45$ & 66 & $29.86 \%$ \\
\hline $46-55$ & 33 & $14.93 \%$ \\
\hline Above 55 & 8 & $3.62 \%$ \\
\hline \multicolumn{3}{|l|}{ Employment status } \\
\hline Own Business & 33 & $14.93 \%$ \\
\hline Retired & 2 & $0.90 \%$ \\
\hline Salaried (Govt/Semi Govt) & 46 & $20.81 \%$ \\
\hline Salaried (Private) & 84 & $38.01 \%$ \\
\hline Self Employed & 56 & $25.34 \%$ \\
\hline \multicolumn{3}{|l|}{ Monthly income (in Rs.) } \\
\hline 10,000 or less & 30 & $13.57 \%$ \\
\hline $10,000-25,000$ & 48 & $21.72 \%$ \\
\hline $25,000-40,000$ & 39 & $17.65 \%$ \\
\hline $40,000-60,000$ & 40 & $18.10 \%$ \\
\hline $60,000-1,00,000$ & 39 & $17.65 \%$ \\
\hline Above $1,00,000$ & 25 & $11.31 \%$ \\
\hline \multicolumn{3}{|l|}{ Education } \\
\hline Below High School & 4 & $1.81 \%$ \\
\hline Diploma & 6 & $2.71 \%$ \\
\hline Graduation & 51 & $23.08 \%$ \\
\hline HSC/Vocational Course & 7 & $3.17 \%$ \\
\hline Post-Graduation & 153 & $69.23 \%$ \\
\hline \multicolumn{3}{|l|}{ No of dependents } \\
\hline 0 & 28 & $12.67 \%$ \\
\hline 1 & 11 & $4.98 \%$ \\
\hline 2 & 39 & $17.65 \%$ \\
\hline 3 & 47 & $21.27 \%$ \\
\hline 4 & 41 & $18.55 \%$ \\
\hline 5 & 28 & $12.67 \%$ \\
\hline More than 5 & 27 & $12.22 \%$ \\
\hline \multicolumn{3}{|l|}{ Region } \\
\hline Khandesh & 5 & $2.26 \%$ \\
\hline Konkan & 4 & $1.81 \%$ \\
\hline Marathwada & 173 & $78.28 \%$ \\
\hline
\end{tabular}




\begin{tabular}{lrr} 
Paschim Maharashtra & 25 & $11.31 \%$ \\
Vidarbh & 14 & $6.33 \%$ \\
\hline
\end{tabular}

\section{Consumption pattern during lockdown}

The initial nationwide lockdown due to COVID-19 in India began from 22 March 2020 for three weeks, i.e., till 14 April 2020. Thereafter it was extended till 3 May 2020. The citizens were required to remain at home unless there is an emergency. Only essential services like hospitals, medical shops, grocery stores, clinics, ambulances, vegetables, etc. were permitted to remain functional whereas all other establishments like schools, colleges, industries, transport services, rail, airlines, hotels, religious places, etc. were closed.

The consumption pattern during lockdown was studied by collecting responses on the level consumption of respondents on 12 major categories of spending. The levels consisted of 5-point Likert Scale starting with very low consumption, lower than normal consumption, normal consumption, higher than normal consumption and very high consumption. The responses were collected in the second week of April.

Table 2 presents the level of consumption of respondents during this lockdown period.

Table 2. Level of consumption during lockdown

\begin{tabular}{cccccc}
\hline & \multicolumn{5}{c}{ Level of Consumption } \\
\cline { 2 - 5 } Categories & Very Low & $\begin{array}{c}\text { Lower than } \\
\text { Normal }\end{array}$ & Normal & $\begin{array}{c}\text { Higher } \\
\text { than } \\
\text { Normal }\end{array}$ & Very High \\
\hline Food & 21 & 50 & 123 & 25 & 2 \\
Personal spending & 163 & 20 & 32 & 6 & 0 \\
Medical and healthcare & 57 & 54 & 95 & 11 & 4 \\
Transport & 159 & 30 & 25 & 5 & 2 \\
Entertainment & 29 & 42 & 77 & 47 & 26 \\
Education & 115 & 41 & 58 & 5 & 2 \\
Utilities & 15 & 31 & 127 & 37 & 11 \\
Housing & 42 & 23 & 144 & 10 & 2 \\
Insurance & 54 & 23 & 132 & 10 & 2 \\
Saving & 73 & 41 & 95 & 9 & 3 \\
Investing & 129 & 17 & 63 & 10 & 2 \\
Debt payments & 84 & 23 & 104 & 6 & 4 \\
\hline
\end{tabular}


The levels for which more than $50 \%$ of responses were received for a particular category are highlighted in the table depicting a higher level of consumption for that category. The results demonstrate that the consumption level for food, utilities, housing, and insurance categories has remained unchanged. Four categories observed very low consumption, namely personal spending, transport, education and investment. Of these, the first 3 categories were obvious since they were not permitted during lockdown but the investment category was not restrained in any manner since all banks, stock exchanges, mutual fund units, and other investment channels were still open for investment but still, people preferred to spend very low on investment. This implies the tendency of people to keep money in safe and highly liquid instruments like a savings account or cash. Additional information shows a medium impact on consumption on categories like medical and healthcare, savings and debt payment. Few respondents preferred to spend very little on savings (33\%) and debt payment (38\%).

Notably, no category attracted significantly higher than normal spending during the lockdown and this signifies that overall spending during the lockdown period has decreased. We can hence conclude that a pandemic like COVID-19 and lockdown decrease the consumption of households.

\section{Effects of demographic variables on the level of consumption}

H1 tries to assess the impact of demographic variables on the level of consumption during the lockdown. The level of consumption of each category is used in the logistics regression model as a dependent variable which is explained simultaneously by all the independent variables.

A cumulative odds ordinal logistic regression with proportional odds was run to determine the effect of age, gender, employment status, number of dependents, incomes, education levels and regions, on the level of consumption during the lockdown. Since employment status violated the assumption of collinearity (VIF $>10)$, the variable was dropped from further analysis. There were proportional odds, as assessed by a full likelihood ratio test comparing the fitted model to a model with varying location parameters, $\chi 2(24)=30.875, \mathrm{p}=.157$ (Refer to Table 3). The deviance goodness-of-fit test indicated that the model was a good fit to the observed data, $\chi 2(324)=219.701, \mathrm{p}=$ 1, but most cells were sparse with zero frequencies in $63.6 \%$ of cells (Refer to Table 4). However, the final model didn't statistically significantly predict the dependent variable 
over and above the intercept-only model, $\chi 2(24)=24.523, \mathrm{p}=.432$ (Refer to Table 5). The odds of males' level of spending was 0.8311 , (95\% CI, 0.357 to 1.9328$)$ times that for non-business owners, $\chi 2(1)=0.184, p=0.668$. Income had a statistically significant effect on the prediction of whether the level of spending was more, $\chi^{2(5)}=10.877, \mathrm{p}=0.05$. The odds of the level of spending of 26-35 age group was 6.665 (95\% CI, 0.66 to 7) times that of above 55 age group $\chi^{2}(1)=2.589, \mathrm{p}=0.108$. The odds of spending of less than Rs. 10000 monthly income group was 0.15 times that of more than Rs. 1,00,000 monthly income, a statistically significant effect $\chi 2(1)=6.800, p=0.009$. The odds of spending of less than 5 number of dependents was less than 1 times that of more than 5 dependents. The odds of spending of the Marathwada region were equal to that of Paschim Maharashtra and the odds of spending of Konkan were 2.30 times that of Paschim Maharashtra (See Table 4).

Table 3. Assumption of Proportional Odds

\begin{tabular}{|c|c|c|c|c|}
\hline \multicolumn{5}{|c|}{ Test of Parallel Lines } \\
\hline Model & -2 Log Likelihood & Chi-Square & df & Sig. \\
\hline Null Hypothesis & 244.609 & & & \\
\hline General & 213.734 & 30.875 & 24 & .157 \\
\hline
\end{tabular}

Table 4. Goodness-of-Fit

\begin{tabular}{lrrr}
\hline \multicolumn{1}{c}{ Chi-Square } & df & \multicolumn{1}{c}{ Sig. } \\
\hline Pearson & 427.012 & 324 & .000 \\
Deviance & 219.701 & 324 & 1.000 \\
\hline Link function: Logit. & & &
\end{tabular}

Table 5. Model Fitting Information

\begin{tabular}{lrrrrr}
\hline Model & -2Log Likelihood & Chi-Square & df & Sig. \\
\hline Intercept Only & 269.133 & & & \\
Final & 244.609 & 24.523 & 24 & .432 \\
\hline
\end{tabular}

The coefficients of GEN and INC are negative and statistically significant at the 5 percent for INC1 and 10\% for INC2 whereas statistically insignificant for GEN, are positive for AGE but statistically insignificant, are negative for DEP, and partially positive for EDU and REG. These results partially confirm H1 of a positive significant relationship between the level of consumption during lockdown and age, gender, number of dependents, incomes, education levels, and regions. 
Table 6. Ordinal logistic regression results of the impact of age, gender, number of dependents, incomes, education levels and regions on level of consumption

\begin{tabular}{|c|c|c|c|c|c|}
\hline \multicolumn{6}{|c|}{ Parameter Estimates } \\
\hline & Category & Estimate $(\beta)$ & $\begin{array}{l}\text { Wald Chi- } \\
\text { Square }\end{array}$ & df & Sig. \\
\hline \multirow{2}{*}{$\begin{array}{l}\text { Threshold } \\
\text { (Consumption) }\end{array}$} & Low & 1.001 & .513 & 1 & .474 \\
\hline & Normal & 5.185 & 11.102 & 1 & .001 \\
\hline \multirow[t]{16}{*}{ Location } & Gender & & & & \\
\hline & Male & -.185 & .184 & 1 & .668 \\
\hline & Female & $0^{a}$ & & 0 & \\
\hline & Age (in Yrs.) & & & & \\
\hline & $18-25$ & 1.806 & 2.215 & 1 & .137 \\
\hline & $26-35$ & 1.897 & 2.589 & 1 & .108 \\
\hline & $36-45$ & 1.740 & 2.203 & 1 & .138 \\
\hline & $46-55$ & 1.606 & 1.830 & 1 & .176 \\
\hline & Above 55 & $0^{a}$ & & 0 & \\
\hline & $\begin{array}{l}\text { Monthly income (in } \\
\text { Rs.) }\end{array}$ & & & & \\
\hline & 10,000 or less & -1.892 & 6.800 & 1 & .009 \\
\hline & $10,000-25,000$ & -1.079 & 3.640 & 1 & .056 \\
\hline & $25,000-40,000$ & -1.005 & 2.905 & 1 & .088 \\
\hline & $40,000-60,000$ & -.162 & .085 & 1 & .771 \\
\hline & $60,000-1,00,000$ & -.216 & .153 & 1 & .695 \\
\hline & Above $1,00,000$ & $0^{a}$ & & 0 & \\
\hline
\end{tabular}

\section{Education}

Below High School

$-19.281$

HSC/Vocational Course

Diploma

$-.750$

.408

1

$$
\text { Graduation }
$$

.401

1.088

Post-Graduation

$$
0^{\mathrm{a}}
$$

$\begin{array}{rrrr}-.493 & .575 & 1 & .448 \\ -.357 & .170 & 1 & .680 \\ -.761 & 1.725 & 1 & .189 \\ -.845 & 2.392 & 1 & .122 \\ -.986 & 2.970 & 1 & .085 \\ -.452 & .577 & 1 & .448\end{array}$




\begin{tabular}{lcccc} 
More than 5 & 0a & & 0 & \\
Region & & & & \\
Marathwada & .048 & .010 & 1 & .921 \\
Vidarbh & -.569 & .470 & 1 & .493 \\
Khandesh & -.880 & .482 & 1 & .487 \\
Konkan & .834 & .532 & 1 & .466 \\
Paschim Maharashtra & $0^{\text {a }}$ & & 0 \\
\hline
\end{tabular}

Link function: Logit.

a. This parameter is set to zero because it is redundant.

\section{Consumption after lockdown}

The impact of COVID-19 on consumption after the lockdown was measured using a 3-point Likert scale where respondents were supposed to state whether their consumption of a particular category is going to increase, decrease or remain constant after lockdown. 1 was coded for a decrease in consumption, 2 for status quo, and 3 for the increase in consumption for each category. In the end average of all categories for each respondent was taken to identify overall consumption after lockdown. The results suggest that mean of consumption after the lockdown was 1.87 signifying an overall decrease in consumption after lockdown. Additional details are mentioned in Table 7.

Table 7. Consumption after lockdown

\begin{tabular}{lrrrr}
\hline Category & Decrease & Constant & Increase & Mean \\
\hline Food & 59 & 111 & 51 & 1.9638 \\
Personal spending & 143 & 34 & 44 & 1.5520 \\
Medical and healthcare & 56 & 81 & 84 & 2.1267 \\
Transport & 114 & 46 & 61 & 1.7602 \\
Entertainment & 102 & 57 & 62 & 1.8190 \\
Education & 65 & 86 & 70 & 2.0226 \\
Utilities & 74 & 80 & 67 & 1.9683 \\
Housing & 70 & 97 & 54 & 1.9276 \\
Insurance & 66 & 100 & 55 & 1.9502 \\
Saving & 102 & 54 & 65 & 1.8326 \\
Investing & 108 & 57 & 56 & 1.7647 \\
Debt payments & 90 & 77 & 54 & 1.8371 \\
\hline & & \multicolumn{3}{c}{ Average } \\
\hline
\end{tabular}


One of the hypotheses (H2) of the study is to know whether this pattern of consumption after lockdown is different for individuals based on age, gender, employment status, number of dependents, incomes, and education levels. The dependent variable, in this case, is the pattern of consumption after lockdown whereas independent variables/factors are all the socio-economic variables as mentioned above.

A Kruskal-Wallis $\mathrm{H}$ test was run to determine if there were differences in the pattern of consumption after lockdown between 7 socio-economic variables. Distributions of the pattern of consumption after lockdown scores were similar for all groups, as assessed by visual inspection of a boxplot. The median pattern of consumption after lockdown scores were not statistically significantly different between groups (Table 8). The results confirm $\mathrm{H} 2$.

\section{Comparison of the pre- and post-lockdown consumption}

The events like recession occur periodically after 8-12 years and many studies have been carried out on its impact on household consumption. The studies have revealed that the events like recession have an adverse impact on household consumption (Gabriela, 2010; Gittins and Luke, 2012; Quelch, 2008; Quelch and Jocz, 2009; Suraju, Aminu, and Oyefesobi, 2018). However, an event like COVID-19 pandemic and lockdown is witnessed by the world for the first time therefore it would be interesting to know how it will affect consumption. This is stated in H3 (The household consumption post COVID-19 lockdown will be significantly lower than pre-pandemic lockdown).

Table 8. Result of Kruskal-Wallis Test

Hypothesis Test Summary

\begin{tabular}{lll}
\hline $\begin{array}{l}\text { Null Hypothesis } \\
\text { (The distribution of consumption after lockdown is } \\
\text { the same across categories of }\end{array}$ & Sig. & Decision \\
\hline Gender & 0.258 & Retain the null hypothesis \\
Age group & 0.370 & Retain the null hypothesis \\
Employment status & 0.212 & Retain the null hypothesis \\
Income & 0.780 & Retain the null hypothesis \\
Education & 0.873 & Retain the null hypothesis \\
Number of dependents & 0.480 & Retain the null hypothesis \\
Region & 0.848 & Retain the null hypothesis \\
\hline
\end{tabular}

Asymptotic significances are displayed. The significance level is 0.05 
To assess whether COVID-19 made any adverse impact on consumption, information about the pre- and post-spending was collected. In pre-lockdown, respondents were asked to specify their level of spending on 12 categories on a 3-point Likert scale starting with low, medium, and high. Then under post-lockdown, they were asked to state whether their spending on a particular category is likely to increase, decrease or remain constant after lockdown. This way, a comparison could be made whether a particular category encounters an increase or decrease or no change of spending.

A Wilcoxon signed-rank test was conducted to determine the effect of the COVID-19 pandemic on change in consumption. The difference scores were approximately symmetrically distributed, as assessed by a histogram with the superimposed normal curve. Data are medians unless otherwise stated.

The results of the test reveal that the lockdown due to COVID-19 is likely to make a statistically significant adverse impact on personal spending $(p<0.05)$, transport $(p<0.05)$, entertainment $(p=0.002)$, savings $(p=0.004)$, investment $(p<0.05)$ and debt payment $(p=0.003)$ category. However, the consumption of food $(p=0.446)$, education $(p=0.067)$, utilities $(\mathrm{p}=0.556)$, housing $(\mathrm{p}=0.151)$ and insurance $(\mathrm{p}=0.317)$ categories are likely to remain unaffected. The lockdown is likely to make a favorable impact on the Medical and Healthcare category which is statistically significant $(\mathrm{p}=0.018)$. The results are partially consistent with the studies and thus partially confirm $\mathrm{H} 3$.

The results indicate that people tend to lower their consumption for non-essential categories like personal spending and entertainment. The adverse impact was observed in the transport category and although it is essential, the impact may be adverse since people restrain from travel to avoid virus contamination. Savings, investment, and debt payments were observed to be adversely affected. The possible reason could be likely loss of income or job due to the economic downturn as a result of the COVID-19 pandemic. Favorable impact on the medical and healthcare category confirms that people give priority to health and well-being than others. 
Table 9. Result of related-samples Wilcoxon signed rank test

\begin{tabular}{llll} 
Hypothesis test summary & & & \\
\hline $\begin{array}{l}\text { Null hypothesis } \\
\text { (The median of differences } \\
\text { between pre-lockdown } \\
\text { and post lockdown consumption of) }\end{array}$ & Sig. & Decision & Impact \\
\hline $\begin{array}{l}\text { Food category equals 0 } \\
\text { Personal spending category equals } 0\end{array}$ & 0.446 & Retain the null hypothesis & No \\
Medical and healthcare category equals 0 & 0.000 & Reject the null hypothesis & Adverse \\
Transport category equals 0 & 0.018 & Reject the null hypothesis & Favorable \\
Entertainment category equals 0 & 0.000 & Reject the null hypothesis & Adverse \\
Education category equals 0 & 0.002 & Reject the null hypothesis & Adverse \\
Utilities category equals 0 & 0.067 & Retain the null hypothesis & No \\
Housing category equals 0 & 0.556 & Retain the null hypothesis & No \\
Insurance category equals 0 & 0.151 & Retain the null hypothesis & No \\
Saving category equals 0 & 0.317 & Retain the null hypothesis & No \\
Investment category equals 0 & 0.004 & Reject the null hypothesis & Adverse \\
Debt payment category equals 0 & 0.000 & Reject the null hypothesis & Adverse \\
\hline
\end{tabular}

Asymptotic significances are displayed. The significance level is 0.05

The categories experiencing no or low impact on consumption like food, education, utilities, housing, and insurance are of the essential type whose consumption can neither be avoided nor postponed.

\section{Impact on earning and employment}

The ongoing COVID-19 outbreak has not only resulted in job cuts but also resulted in pay cuts across the world. (Goel, Mahesh, Nikhil, and Furquan, 2020; Simmon, 2020). Retailers expect around 80,000 job losses due to lockdown (PTI, 2020). Fed estimates that job losses due to COVID-19 could total 47 million and the unemployment rate may hit 32\% (Jeff, 2020). In India, according to a CII CEOs Snap Poll, the majority of the firms are expecting a significant decline in revenues, falling demand and job losses. (PTI2, 2020). Estimates released by the National Sample Survey (NSS) and Periodic Labour Force Surveys (PLFS), on March 31, suggested that over 136 million nonagricultural jobs are at immediate risk. Workers without formal employment contracts, casual laborers, those who work in small companies, and the self-employed, are the most vulnerable. Over 1.5 lakh people across India's various IT firms are expected to lose their jobs in the coming months (Swathi, 2020). All these articles suggest that earning and job scenario around the globe is uncertain. 
Of the 221 participants recruited to the study, 112 expect that COVID-19 outbreak will negatively impact their earning, 68 expect positive impact while 41 assume no change. A chi-square goodness-of-fit test was conducted to determine whether the outbreak will adversely impact their earning. The minimum expected frequency was 73.3. The chisquare goodness-of-fit test indicated that the expectations of respondents concerning earning (positive, negative or no change) were statistically significantly different $(\chi 2(2)=$ $34.869, \mathrm{p}<.05$ ) and thus confirms H4 (Table 10).

\section{Table 10. Impact on earnings}

\begin{tabular}{lr}
\multicolumn{2}{c}{ Test statistics } \\
\hline \multicolumn{2}{c}{ Impact on earning } \\
\hline Chi-Square & $34.869^{\mathrm{a}}$ \\
Df & 2 \\
Asymp. Sig. & .000 \\
\hline
\end{tabular}

The impact of lockdown on the employment was measured using the chi-square goodness-of-fit test. Whereas 22 expected to lose their job, 123 are confident of retaining their current job and 76 are unsure. This implies that people are expecting a reduction in earning in their current job. The minimum expected frequency was 73.3. The chi-square goodness-of-fit test indicated that the expectations of respondents regarding job (retain, lose, or unsure) was statistically significantly different $(\chi 2(2)=69.348, \mathrm{p}<.05)$. However, the result is statistically significantly different but the impact is not adverse (123 respondents expect to retain job) hence does not confirm H5 (Table 11).

\section{Table 11. Impact on Employment}

\begin{tabular}{lr}
\multicolumn{2}{c}{ Test statistics } \\
\hline \multicolumn{2}{c}{ Impact on job } \\
\hline Chi-Square & $69.348 \mathrm{a}$ \\
Df & 2 \\
Asymp. Sig. & .000 \\
\hline a. 0 cells $(0.0 \%)$ have expected frequencies less than 5 . The minimum expected cell frequency is 73.7.
\end{tabular}


Additional information about earning and employment reveal that 59\% of respondents are ready to work at lower remuneration and they give priority to spending on healthcare and low priority to investment. The majority of the businessmen (more than $50 \%$ ) say that they will protect their cashflows, make most of their current clients and focus on core competencies to tackle adverse business conditions that may arise out of COVID-19.

\section{Adoption of debt moratorium}

Reserve Bank of India vide circular RBI/2019-20/186 dated March 27, 2020, permitted all commercial banks, co-operative banks, and NBFCs to grant a moratorium of three months on payment of all installments falling due between March 1, 2020, and May 31, 2020 , in respect of all term loans. Interest, however, shall continue to accrue on the outstanding portion of the term loans during the moratorium period (RBI, 2020). The deference of payment will not impact the borrower's credit score. In this regard, researchers tried to know the respondents' decision of opting for debt moratorium.

Out of 221 respondents, $54 \%$ of respondents had some types of term loans. Out of these, 51\% had home loans, $39 \%$ had personal loans, $29 \%$ had car loans, $24 \%$ had business loans and rest had other loans like education loans, gold loans, credit card loans, etc. Regarding the decision of option for the moratorium, $28 \%$ were interested in extending loan Equated Monthly Instalments (EMIs), 46\% were not interested and 26\% were undecided. The results indicate that the majority respondents are ready to pay their EMIs during this tenure.

\section{CONCLUSIONS}

Existing study aimed at studying the impact of COVID-19 pandemic on household consumption, earning and employment in India. As per the data collected and subsequent analysis it is found that there is a significant decrease in the consumption of households, earning and employment of individuals. Economic recovery seems longer than expected that necessitates us to adopt certain measures to protect economically vulnerable peoples. Therefore, we propose the need of social protection and universal basic income to the most economically vulnerable section of the society. The present paper also highlights and adds to the existing literature the relationship between COVID-19 and its effect on 
various socio-economic parameters. It will help to understand the parameters that need to be focused during pandemic and a suitable measure can be taken accordingly.

In this study, the effect of COVID-19 and lockdown was studied on the consumption behavior of households during and after the lockdown in Maharashtra State, India. The results suggest that during a countywide lockdown due to COVID-19 in India that began from 22 March 2020 for six weeks, the level of consumption of food, utilities, housing, and insurance categories remained unchanged whereas personal spending, transport, education and investing witnessed sharp fall in consumption. The research signifies that overall spending during the lockdown period decreased significantly. The results partially confirm a positive significant relationship between the level of consumption during lockdown and age, gender, number of dependents, incomes, education levels, and regions. The results reveal that when compared to pre-lockdown consumption, the lockdown is likely to make a statistically significant adverse impact on personal spending, transport, entertainment, savings, investments, and debt payment. However, the consumption of food, education, utilities, housing, and insurance is likely to remain unaffected. The lockdown is likely to have adverse effect on the savings, consumption and average recovery time for individuals. The long recovery time along with effects on earning and employment of individuals will necessitate us to have social protection without which there will be favourable impact on increasing medical and healthcare expenditure indicating the priority of people to health and well-being.

The study was limited by sample size which was not evenly distributed across the regions and since many experts fear that COVID-19 will result in severe job cuts, further research can be conducted to study the impact of COVID-19 outbreak on employment and job in sectors like IT, transport, travel and tourism, aviation, hospitality, and automobiles.

\section{REFERENCES}

Almond, D. 2006. Is the 1918 influenza pandemic over? Long-term effects of in utero influenza exposure in the post-1940 U.S. population. Journal of Political Economy 114 (4): 672-712. 
Ambrus, A., F. Erica, and G. Robert. 2020. Loss in the time of Cholera: long-run impact of a disease epidemic on the urban landscape. American Economic Review 110 (2): 475-525.

Amory, M., M. Markhvida, S. Hallegatte, and B. Walsh. 2020. Socio-Economic Impacts of COVID-19 on Household Consumption and Poverty. Retrieved 21 April 2020 from https://www.researchgate.net/publication/341357597 Socio-

Economic_Impacts_of_COVID-19 on_Household_Consumption_and_Poverty.

Arpit, G., M. Anup, and W. Bartek. 2021. Explaining the income and consumption effects of COVID in India. National Bureau of Economic Research Working Paper Series (No. 28935).

Atkeson, A. 2020. what will be the economic impact of COVID-19 in the US? Rough estimates of disease scenarios. National Burean of Economic Research Working Paper Series (No. 26867).

Barro, R. J., F. U. José, and W. Joanna. 2020. The coronavirus and the great influenza pandemic: lessons from the "Spanish Flu" for the coronavirus' potential effects on mortality and economic activity. National Bureau of Economic Research Working Paper Series (No. 26866).

Bleakley, H. 2007. Disease and development: evidence from hookworm eradication in the American South. Quarterly Journal of Economics 122 (1): 73-117.

Bloom, D. E. and S. M. Ajay. 1997. Does the AIDS epidemic threaten economic growth? Journal of Econometrics 77 (1): 105-24.

Davis, G. 2021. The many ways COVID-19 affects households: consumption, time, and health outcomes. Rev Econ Household 19: 281-289. Retrived from https://doi.org/10.1007/s11150-021-09563-w.

Emma, C. 2020. This is how India is reacting to the coronavirus pandemic. Retrieved from https://www.weforum.org/agenda/2020/03/quarantine-india-covid-19coronavirus/

Haiqiang, C., W. Qian, and Q. Wen. 2020. The impact of the COVID-19 pandemic on consumption: learning from high frequency transaction data. Available at SSRN: https://ssrn.com/abstract=3568574 or http://dx.doi.org/10.2139/ssrn.3568574.

Fan, V. Y., T. J. Dean, and H. S. Lawrence. 2016. The inclusive cost of pandemic influenza risk. National Bureau of Economic Research Working Paper Series (No. 22137). 
Fernandes, N. 2020. Economic effects of coronavirus outbreak (COVID-19) on the world economy. IESE Business School Working Paper (No. WP-1240-E). Available at SSRN: https://ssrn.com/abstract=3557504 or http://dx.doi.org/10.2139/ssrn.3557504.

Gabriela, S. 2010. Changes in consumer behaviour during an economic crisis. Economic Sciences Series 10 (2): 784-787.

Gittins, P. and S. Luke. 2012. Impact of the recession on household spending. Office for National $\begin{array}{lllll}\text { Statistics. } & \text { Retrieved } & 25 & \text { April } & 2020\end{array}$ https:/webarchieve.nationalarchieves.gov.uk/20160105160709/.

Goel, S., K. Mahesh, V. Nikhil, and M. Furquan. 2020. Coronavirus outbreak: Job loss, pay cut on cards for millions in India. Retrieved 27 April 2020 from https://www.deccanherald.com/business/business-news/coronavirus-outbreakjob-loss-pay-cut-on-cards-for-millions-in-india-821019.html.

Gormsen, N. J. and S. J. Ralph. 2020. Coronavirus: Impact on stock prices and growth expectations. National Bureau of Economic Research, Inc Working Paper 27387.

Jeff, C. 2020. Coronavirus job losses could total 47 million, unemployment rate may hit $32 \%$, Fed estimates. Retrieved 29 April 2020 from https://www.cnbc.com/2020/03/30/coronavirus-job-losses-could-total-47million-unemployment-rate-of-32percent-fed-says.html.

Paula, E. and G. Liviu. 2014. The relationship between income, consumption and gdp: a time series, Cross-Country Analysis, Procedia Economics and Finance (23): 1535 - 1543.

PTI. 2020. Coronavirus impact: Retailers expect around 80,000 job losses due to lockdown, says survey. Retrieved 29 April 2020 from https://www.thehindubusinessline.com/economy/coronavirus-impact-retailersexpect-around-80000-job-losses-due-to-lockdown-says-survey/article31280985.ece.

PTI2. 2020. Lockdown would have deeper impact; 52\% CEOs foresee job losses: CII Snap Poll. Retrieved 20 April 2020 from https://economictimes.indiatimes.com/jobs/lockdown-would-have-deeper-impact52-ceos-foresee-job-losses-cii-snap-poll/articleshow/74992585.cms?from =mdr.

Quelch, J. 2008. How to market in a recession? The Financial Times of London. Retrieved 25 April 2020 from wmw.ft.com.

Quelch, J. A. and K. E. Jocz. 2009. How to market in a downturn? Harvard Business Reviem. Retrieved 25 April 2020 from https://hbr.org/2009/04/how-to-market-in-adownturn-2. 
RBI. 2020. COVID-19 - Regulatory Package. Retrieved 1 May 2020 from https:/ / www.rbi.org.in/Scripts/NotificationUser.aspx?Id=11835\&Mode $=0$

Sachs, J. and M. Pia. 2002. The Economic and Social Burden of Malaria. Nature, 415: 680685.

Saraswathy, M. 2021, COVID-19 job impact: Which sectors lost the most people and which ones hired the most in 2020? Retrieved 31 August 2021 from https://www.moneycontrol.com/news/business/economy/COVID-19-jobimpact-which-sectors-lost-the-most-people-and-which-ones-hired-the-most-in2020-6334431.html.

Scott, R. B., R. A. Farrokhnia, M. Steffen, P. Michaela, and Y. Constantine. 2020. How does household spending respond to an epidemic? Consumption during the 2020 COVID-19 pandemic. NBER Working Papers (26949), National Bureau of Economic Research, Inc.

Simmon, K. 2020. Jobs destroyed worldwide as coronavirus sparks recession. Retrieved 26 April 2020 from https://economictimes.indiatimes.com/news/economy/indicators/jobs-destroyedworldwide-as-coronavirus-sparks-recession/articleshow/74978068.

Silvius, S., R. Radu, V. Sapira, B. Bratoveanuand, and F. Mirel. 2020. Consumer Behavior in Crisis Situations. Research on the Effects of COVID-19 in Romania. Economics and Applied Informatics, "Dunarea de Jos" University of Galati, Faculty of Economics and Business Administration, issue 1, pages 5-13.

Suraju, A., S. Aminu, and O. Oyefesobi. 2018. Economic recession and changing consumption patterns: Evidence from Lagos metropolis. KIU Journal of Humanities 3 (2): 67-79.

Swathi, M. 2020. Coronavirus impact | IT firms start issuing pink slips; around 1.5 lakh employees may lose their jobs. Retrieved 30 April 2020 from https://www.moneycontrol.com/news/business/coronavirus-impact-it-firms-startissuing-pink-slips-around-1-5-lakh-employees-may-lose-their-jobs-5101181.html.

Young, A. 2005. the gift of the dying: the tragedy of aids and the welfare of future African generations. Quarterly Journal of Economics 120 (2): 423-66. 